\title{
COOPERATIVES BEFORE COOPERATIVE LAW: BUSINESS LAW AND COOPERATIVES IN SPAIN, $1869-1931$ *
}

\author{
TIMOTHY W. GUINNANE \\ Yale University ${ }^{\text {a }}$ \\ SUSANA MARTÍNEZ-RODRÍGUEZ \\ University of Murcia ${ }^{\mathrm{b}}$
}

\begin{abstract}
Studies of Spanish cooperatives date their spread from the Law on Agrarian Syndicates of 1906. But the first legislative appearance of cooperatives is an 1869 measure that permitted general incorporation for lending companies. The 1931 general law on cooperatives, the first act permitting the formation of cooperatives in any activity, reflects the gradual disappearance of the cooperative's «business» characteristics. In this paper, we trace the Spanish cooperative's legal roots in business law and its connections to broader questions of the freedom of association, the formation of joint-stock enterprises and the liability of investors in business and cooperative entities. Our account underscores the similarities of the organizational problems approach by cooperatives and business firms, while at the same time respecting the distinctive purposes cooperatives served.
\end{abstract}

Keywords: cooperative, general incorporation, business enterprise, freedom of association, freedom of contract

JEL code: N43, N23, K20

\footnotetext{
* Received 9 June 2010. Accepted 28 December 2010. An earlier version of this paper appeared in Spanish as «Fue alguna vez la cooperativa una sociedad por acciones? Leyes de negocios y de cooperativas en España (1869-1931)», available as working paper DT-0908 at: http://www.aehe.net/publicaciones.html. This research has been made possible by the Economic History Program of the Economic Growth Center and the MacMillan Center for International and Area Studies at Yale University, as well as the Spanish Ministry of Education and Science's Project NISAL SEJ2007-6084. Guinnane acknowledges the entities that have funded his research on the German credit cooperatives, as well as his participation in a project on the legal form of enterprise with Ron Harris, Naomi Lamoreaux and Jean-Laurent Rosenthal. The authors also wish to thank Salvador Almenar, Mercedes Bernal, Albert Carreras, María Jesús Espuny, Eric Hilt, Naomi Lamoreaux and Xavier Tafunell for their valuable comments on an earlier version. A preliminary version was published at Documentos de trabajo de FUNCAS, «Did the cooperative start life as a joint-stock company? Business law and cooperatives in Spain, 1869-1931» (2010), no. 567.

a Department of Economics, Yale University, Box 208269, New Haven, CT 06520-826, USA. timothy.guinnane@yale.edu

b Department of Economics — Economic History Section, Campus de Espinardo, 30100 Espinardo-Murcia, Spain. susanamartinezr@um.es
} 


\section{RESUMEN}

Los estudios acerca de las cooperativas española datan su difusión a partir de la Ley de Sindicatos Agrícolas de 1906. No obstante, la primera legislación al respecto apareció en 1869, a propósito de la libertad para crear compañías anónimas y de crédito. La ley de 1931 fue la primera sobre cooperativas, permitiendo la creación de cooperativas de todo tipo, y reflejando la gradual desaparición de las cooperativas con características de «empresas». En este artículo perfilamos con detalle el origen legal de las cooperativas españolas en la legislación mercantil; su conexión con cuestiones más generales, como la libertad de asociación, la formación de sociedades anónimas, y la responsabilidad legal asumida por los inversores, tanto en las cooperativas como en otras fórmulas de negocios. Enfatizamos las concomitancias entre la organización de las cooperativas y las fórmulas mercantiles, como también señalamos los propósitos particulares a los que obedecieron las cooperativas.

Palabras clave: cooperativas, formación de sociedades anónimas, fórmulas mercantiles, libertad de asociación, libertad para contratar

\section{INTRODUCTION}

Much of the banking, retail and farm-related sectors in several European economies have been conducted along cooperative lines since the late $19^{\text {th }}$ century. Yet the economic history of cooperative institutions remains curiously underdeveloped. The older literature on European cooperatives stresses the ideological motivations for their existence. Economic historians have more recently stressed the ways in which cooperatives can ameliorate specific economic problems such as hold-up and asymmetric information ${ }^{1}$. The recent perspective offers the chance to understand both these institutions' success and the social and economic contexts in which they worked, and those in which they did not.

Neither literature has paid focused attention to developments in the law under which these enterprises were organized. Neglect of the law is unfortunate. The distinction between a business firm and a cooperative is at least partly legal. More importantly, the period in which European cooperatives

\footnotetext{
1 See, for example, Henriksen (1999), who argues that cooperative creameries worked better than private alternatives because the former could commit not to take advantage of dairy farmers' sunk investments; Galassi (2001), who argues that credit cooperatives worked differently in southern Italy, thus bolstering the idea of "social capital» as the basis for credit cooperatives; and Guinnane (2001), who pushes this same idea in a different way for Germany.
} 
first developed, the mid- to late- $19^{\text {th }}$ century, is also a period in which lawgivers developed and refined the law of business enterprise. As we will demonstrate, the issues that arise in defining and limiting cooperatives are specific versions of more general issues concerning partnerships, corporations and other business enterprises. Understanding the development of cooperative law helps us to understand the development of company law.

Neglecting the history of cooperative law has broader implications, as the Spanish case we consider illustrates. The two most important acts that address Spanish cooperatives specifically date back to 1906 and 1931, and these measures rightly receive considerable attention in the scholarly literature. But Spain had cooperatives long before 1906. We argue that scholars have missed the existence of Spanish cooperatives that were often organized under statutes intended for business firms. The Spanish case also highlights important, interlocking legal and economic controversies. European societies in the latter part of the $19^{\text {th }}$ century faced three related debates over the nature of organizations. Some focused on the rights of people as citizens, and others were more specific to business firms. These debates were central to the growth and success of cooperatives, partly because organizations like cooperatives had been suppressed in the name of restricting political rights, partly because cooperatives shared features with business firms that made the cooperatives equally sensitive to developments in business law.

Cooperatives nearly everywhere faced three legal issues in this period: Freedom of association: Until the late $19^{\text {th }}$ century in most of Continental Europe, the right of citizens to associate, whether explicitly for political purposes or not, could be limited or regulated by the State. One reason for the development of distinct business organizations and business codes was that business firms usually fell outside the political oversight of the police. Cooperatives, on the other hand, were often harassed on the grounds that they were illegal associations, accused of having a political goal. For cooperatives, it was thus critical either to be recognized as a default "permitted association» or as a business organization. Investor liability: An investor's ability to own all or part of a firm without risking more than his original investment was hotly debated in the early- to mid-1 $9^{\text {th }}$ century. Many Continental countries allowed limited partnership, in which all but one owner enjoyed limited liability. But most countries still drew the line at firms in which no investor had unlimited liability. Cooperatives themselves held mixed views on limited liability, but increasingly, many cooperative leaders saw limited-liability membership as crucial to their movement's health. Incorporation and the division of capital into shares: In most European countries, the right to form a corporation was strictly controlled by the State until sometime in the mid- $19^{\text {th }}$ century. General incorporation was not granted in some countries until the $1870 \mathrm{~s}^{2}$.

${ }^{2}$ Guinnane et al. (2007) trace the history of the relevant company law in England, France, Germany and the United States. 
The introduction of general incorporation affected cooperatives in two related ways. In some countries, cooperatives organized themselves under the generalincorporation statutes. More generally, the corporate form closely resembled what many cooperatives wanted for themselves: an enterprise form that had legal personality; limited liability for owners; and capital divided into shares such that the entity could exist in the face of a changing membership. The essential legal similarity of the corporation and the cooperative will surprise those accustomed to thinking of cooperatives as the very opposite of the corporation, and often formed to combat the power of corporations. But at their heart, both the corporation and cooperative are vehicles for assembling capital and undertaking contracts that do not depend on the enterprise having any particular set of investors.

\section{TWO PATHS TO COOPERATIVE LAW}

European cooperative law developed in one of two general ways. In the United Kingdom and Germany, cooperatives were organized under their own law. In France, Italy and Portugal, cooperatives were treated as a special case under more general statutes governing business firms. Spain at first followed the «French» approach and only later enacted special cooperative law. To make clear these two models, we briefly consider the German and French examples.

Prussian legal developments shaped cooperative law in Germany. The first Prussian cooperative law dates back to 1867. The cooperative leader Hermann Schulze-Delitzsch wanted two things from legislation: recognition that cooperatives were not subject to police oversight, and the right for cooperatives to act as a legal entity. These two desiderata reflected the cooperative movement's history to that point ${ }^{3}$. The first all-German commercial code was completed in 1862, and could have written cooperatives into the German business code, as a legal form alongside corporations, partnerships, etc. But this did not happen. The 1867 Prussian Cooperatives Law did, however, draw heavily on the business code; most notably, the cooperatives were given something approaching legal personality by strict analogy to the rights of commercial partnerships under the commercial code. Cooperatives were able to acquire these and other rights by registration. The cooperatives successfully evaded demands to require permission to exist, as had been the case with corporations. The Prussian Law of 1867 thus addressed two of the issues listed at the outset: cooperatives were freed from most police harassment, and the law recognized them as economic enterprises.

\footnotetext{
${ }^{3}$ Guinnane (2010a) details the harassment of German cooperatives on political grounds, as well as the expenses incurred because the law did not treat them as legal persons.
} 
The next major cooperatives act in Germany came into effect in 1889, and applied to the entire country. This Act again remained outside the commercial code, but here we see the role the cooperatives play in broader discussions of enterprise law in Germany. The 1889 Act legalized a cooperative form in which every member had limited liability. Discussions of this innovation engaged a public concerned about the nature of the corporation more generally. In response to a stock-market bubble in the early 1870 s, the German government had made it much harder for investors to form a corporation. Some observers were leery of permitting a limited-liability cooperative, something that looked much like a corporation for investors with meager assets ${ }^{4}$. Thus, by 1889 , the German cooperatives had achieved a legal status that afforded them the right to exist as organizations, the right to act as a single economic entity and the same limited-liability status that applied to business corporations. And while German cooperative law drew freely on concepts in the business code, the cooperatives themselves remained outside the business code ${ }^{5}$.

The French approach to cooperative law was different: cooperatives were legally introduced in the Company Law of 1867 as «variable capital corporations», and were explicitly embedded in the commercial code. Thus, the first French cooperatives were legally a sub-species of a commercial corporation. Owing to the high capital stock requirements of France's 1867 law, other kinds of cooperatives, such as those built on Germany's Raiffeisen model, did not gain ground in France until much later. France also adopted ad hoc measures to enable cooperatives not allowed under company law. Most importantly, the 1884 law on associations officially granted workers the right to unionize and, more generally, allowed professional groups to organize into entities to assist them in earning a livelihood. The latter provision spurred the growth of cooperatives. Not until 1894 did France pass legislation specifically targeting cooperatives (Ingalls and Herrick 1914, pp. 328-333).

Spain's cooperative law developed largely in imitation of the French, and this feature may explain why scholars of the Spanish cooperative movement have misunderstood the Spanish cooperative's mercantile roots. Garrido (2007, pp. 183-200) rightly stresses that the Law on Agrarian Syndicates of 1906 was the essential legal step for most rural cooperatives. But many Spanish cooperatives had organized under the commercial codes as early as 1867. Most of these cooperatives were small credit unions similar to the

4 Guinnane (2001) provides more information on the development of German cooperatives, while Guinnane et al. (2007) provide a comparative account of the law of business enterprise in France, Germany, the United States and the United Kingdom in this period.

5 Schulze-Delitzsch's approach to cooperative law was in turn heavily influenced by the English treatment of Friendly Societies. The 1862 «Act to Consolidate and amend the Laws relating to Industrial and Provident Societies» did not change the essential feature of the 1852 "Industrial and Provident Societies Act». Both gave these organizations a form of legal personality. 
German Raiffeisen rural cooperatives, agricultural supply cooperatives or small consumer cooperatives. After 1906, agricultural cooperatives generally organized under the agrarian syndicates law. Until 1931, the rest relied on the 1887 law on associations ${ }^{6}$.

\section{BUSINESS ENTITIES: THE COMMERCIAL CODE OF 1829 AND ITS REPEAL IN 1848}

Prior to the 1829 Commercial Code, Spanish firms relied on multiple sources of commercial law ${ }^{7}$. The most influential among many existing ordinances were the Bilbao Ordinances (Royal Edict, December 2, 1737), which recognized the existence of several business entities: general partnerships, limited partnerships and corporations. The 1829 Code upheld this triad, while introducing important innovations with respect to incorporation. What the Bilbao Ordinances called «corporations» were associations whose existence was brief and limited to the specific purposes described in an agreement (Tapia 1839, pp. 17-19; Petit 1980, p. 56). Under the new commercial code, the sociedad anónima became a standardized legal entity in which capital was owned by investors with limited liability.

The 1829 code did not require Spanish corporations to have royal or government authorization. Corporations simply had to comply with the principle of publicity. Only corporations enjoying special privileges such as specific monopoly rights required royal approval (Art. 294) ${ }^{8}$. The Code recognized two other legal forms of enterprise, the ordinary partnership and the limited partnership. In the former, all partners had unlimited liability; in the latter, some but not all could have limited liability. The code required registration for all three legal forms in the new provincial commercial registry ${ }^{9}$.

This freedom to incorporate business enterprises was unparalleled in Europe and surprising given Ferdinand's conception of absolute monarchy. This represented a true revolution in terms of contemporary legislation. Elsewhere in Europe at the time, incorporation required the express consent of the government, since a business enterprise with multiple investors, all of whom enjoyed limited liability, was considered suspect (Tortella 1968). Even the most advanced European economies then required explicit charters to form a corporation (Guinnane et al. 2007). The code's author, Sáinz de Andino (an expert in Civil and Business Law and later member of the Senate),

\footnotetext{
${ }^{6}$ Garrido (2007) focuses on agricultural cooperatives, which were certainly the most important as a share of the economy. He emphasizes the tax advantages of these cooperatives as being instrumental to their spread.

7 For a detailed account of previous commercial legislation, particularly in relation to the Commercial Consulate of Catalonia, see Sarrión Gualda and Espuny Tomás (1989).

8 «Art. 294. Cuando las compañías anónimas hayan de gozar de algún privilegio que YO les conceda para su fomento, se someterán sus reglamentos a mi soberana aprobación».

9 Article 22 additionally established the creation of an index of all registered documents.
} 
probably gave the best explanation for this approach during his appearance before the Senate to push for a more restrictive law on the incorporation of public limited companies ${ }^{10}$. Sáinz de Andino stressed the need to promote capital accumulation in Spain, and in particular to encourage the repatriation of capital from Spain's lost American colonies.

The Spanish case reflects an inversion in the sequence of legal developments seen elsewhere in Europe. Long before they had civil liberties such as freedom of speech, assembly and association, the Spanish people enjoyed an usual form of freedom of contract: the right to form corporations as well as other business entities. But the Spanish still did not enjoy freedom of association. Most other associations remained illegal under the Penal Code of 1822 (Art. 317), which forbad unauthorized meetings of four or more people (Art. 300). This restriction reflects an absolutist regime bent on quelling even the smallest sign of opposition. Neither the Liberal government of 1833 nor the Penal Code of 1848 improved the situation ${ }^{11}$.

\subsection{Limits to Freedom of Contract under the Liberals: The Law of 1848}

The Madrid stock market crash of 1845 led the public to a more negative view of the sociedad anónima, although business enthusiasm for the form remained unshaken (Gómez de la Serna 1878). In fact, there was a noticeable increase in the number of public corporations after the crash. Beginning in 1846, successive governments introduced measures aimed at regulating incorporation $^{12}$. In 1847 , the government assumed the company oversight role previously exercised by Commercial Courts ${ }^{13}$. A year later, a law was passed prohibiting the creation of all joint-stock companies, as well as limited partnerships, without express government authorization. Article 2 of this bill also required specific laws for the establishment of «banks of issue and associated banking institutions, or the construction of general roads, canals

10 Parts of this speech can be found in Rubio (1950).

11 During this period, there were only minor advances with respect to freedom of association. The Royal Decree of 1839 sanctioned the creation of a mutual insurance association similar to a Friendly Society, or a montepio, in Barcelona. This decree later served as umbrella legislation for the creation of other similar legal entities. At the same time, however, freedom of contract was curtailed with the repeal of the section on joint-stock companies of the 1829 Commercial Code. We refer to the Royal Order of February 28, 1839, authorizing the creation of mutual aid associations. Reprinted in Alarcón Caracuel (1975, pp. 314-315).

12 Early in 1846 (January 19), the first Ramón María Narváez government presented the Senate with a bill on public limited companies that would make their creation «subject to consent through a Royal Decree authorizing its creation». (Art. 1) This government's short life, combined with the instability of those succeeding it, meant the bill remained paralyzed until the following year. On February 9, 1847, a Royal Order was printed in the Official State Bulletin banning Commercial Courts from sanctioning social pacts or agreements.

13 Royal Decree (April 15, 1847) containing the basic elements of the bill signed by Nicomedes Pastor Díaz, Minister of Trade, Industry, and Public Works. 
for navigation, and railroads» (Art. 2, par. 1) ${ }^{14}$. During the short-lived Progressive government (1854-1856), several special laws were passed granting some sectors greater freedom to set up joint-stock companies, adversely affecting investors who did not enjoy such privileges. A 2-month grace period was provided so that joint-stock companies created prior to this law could meet the terms of the new legislation. Those unable to comply were to be dissolved (Bernal Lloréns 2004).

The remainder of the period until the Liberal revolution of 1869 saw only a modest relaxation of the restrictions on new firms. In 1856, new laws on banks and credit institutions simplified incorporation for financial firms, allowing an influx of foreign capital, particularly from France. The new laws revealed the existence of overseas investors interested in Spain, as well as the lack of proper legal business framework to allow foreign investment. Tortella (1968, pp. 77-79) has shown how the increase in the number of credit institutions in the years following the law stands as evidence of its success, as well as confirmation of how restrictive the 1848 law had been for the economic development of the country.

\section{THE JOINT-STOCK COMPANY LAW OF 1869}

The liberal revolution of 1868 began a process of legal modernization, beginning with the protection of civil liberties (Piqueras Arenas 1992; Bernal and Parejo 2001). The 1868 government then moved to introduce a liberal economic organization. In 1869, the provisional revolutionary government repealed the law of 1848 and temporarily reinstated the Commercial Code of 1829, pending a new law on joint-stock companies and a new commercial code $^{15}$. Shortly before this, the Minister of Public Works Echegaray had presented a Royal Decree outlining some of the principles guiding the new code ${ }^{16}$. These included greater freedom of contract as well as the inclusion of recent European legal innovations, such as the cooperative ${ }^{17}$. The hopes which some members of the political class had placed in these reforms are documented in that year's Journal of Debates of the Cortes: Moret (then a young liberal MP, later an important politician and economist) praised the cooperative as a

\footnotetext{
14 «bancos de emisión y cajas subalternas de éstos, o la construcción de carreteras generales, canales de navegación y caminos de hierro (Art. 2. párrafo 1)».

15 Regarding the new law on joint-stock companies, see «Diario de las Cortes Constituyentes» (1869a, b, e, f, g).

16 "Real Decreto por el que se aprueban las bases para el futuro Código de Commercio» (1869).

17 «Quinta. En lo que se refiere a los contratos de comercio en general a sus formas y efectos, tendrán que ampliarse las de las compañías mercantiles constituidas, a las ya constituidas y en práctica en Europa, que no se hallan en el código, como bancos de emisión y descuento, montes de crédito territorial o agrícola, sociedades con responsabilidad más o menos limitada, cooperativas, mixtas de socios contribuyentes por acto benéfico sin retribución y socios partícipes de resultados y beneficios, etc. sino que se establecerán en lo posible reglas generales que puedan comprender todas las demás conocidas hoy».
} 
means of improving workers' livelihoods; Garrido, also an MP and a well-known champion of the cooperative movement, led a Parliamentary commission investigating the conditions of the working class ${ }^{18}$.

That year's law on joint-stock companies explicitly included cooperatives $^{19}$. The preamble to the draft law on the freedom of incorporation for joint-stock companies and credit institutions stated that the law's objective was to "give the Spanish people back the freedom to create industrial associations, to set up business enterprises of any kind, to reinvigorate credit» $^{20}$. The only restriction was the principle of publicity, which substituted for state control the requirement to publicly and periodically disclose a company's financial statements (Matilla Quiza 1996, pp. 397-399). The law itself broke no new ground, as it simply repealed the law of 1848 in favor of the Commercial Code of 1829. But the measure was groundbreaking in its principles, inspired by the ideals of freedom of association and contract. The law stated that new firms needing to contract with third parties to undertake their business could be incorporated under any of the three forms established in its Article $2^{21}$. Article 10 underscored the fact that companies incorporated under this new law were not subject to monitoring and control by the government. Investor rights as well as corporate obligations were the "exclusive purview of the courts».

\subsection{The First Legal Mention of Cooperatives}

The final version of the bill recognized cooperatives as lawful entities and granted them legal personality. This is the first mention of cooperatives in the Spanish legal corpus. The inclusion of cooperatives in this legislation reflects the efforts of a group of liberal economists. In the original draft of law, presented before the Cortes on March 22, 1869, cooperatives were mentioned only once and rather indirectly. As part of the legal guarantee of freedom of incorporation for joint-stock companies, credit institutions and a long list of others, Article 1 established a clause extending this right to «other associations whose purpose is to assist and cooperate with industry or trade» ${ }^{22}$.

18 Their addresses to the Cortes appear in the Journal of Debates of 1869: «Diario de las Sesiones Constituyentes» (1869c, d).

${ }^{19}$ A summary of the development of this law can be constructed from the following official documents: (1) draft of law of March 22, 1869, Journal of Debates of the Constitutional Cortes, Appendices 1-33; (2) May 20 ruling, Journal of Debates of the Constitutional Cortes, Appendices 1-78; enacted law, Journal of Debates of the Constitutional Cortes, October 6, 1869; amendment, Journal of Debates of the Constitutional Cortes, Appendices 3-84; defense, Journal of Debates of the Constitutional Cortes, October 6, 1869.

20 «devolver al pueblo español su libertad de fundar sociedades industriales, de establecer empresas de cualquier género, de dar vida al crédito».

21 These regulations were to be enforced by fines of «100 to 1000 escudos» for firms that neglected to make these documents public (Art. 12).

22 «Diario de las Sesiones Constituyentes» (1869). 
The draft was sent for analysis to a commission that included some of the most important liberal economists of the period ${ }^{23}$.

The associations contemplated by the bill were to «be established by public deed in one of the ways prescribed by the first section of the Commercial Code, Book 2, Title II ${ }^{24}$. The committee also added the following paragraph: «Associations which legally do not have mercantile characteristics, and those cooperatives in which the number of investors has been fixed, can adopt in their deed of incorporation the legal form which its members consider fit $^{25}$. The purpose was to create a simple legal arrangement under which these groups could acquire legal personality. The law did not designate the cooperative as a mercantile entity, but it did not rule it out as one either ${ }^{26}$. As a general rule, the Spanish Commercial Code of 1885 did not apply to cooperatives; the code only applies to the rare commercial cooperatives that tried to earn profits. The problem lay in the absence of legislation on noncommercial cooperatives prior to the Law on Associations of (1887) («Ley de Asociaciones» 1887).

To legally constitute a cooperative in accordance with the law of 1869 , an organization's charter had to be registered through a notarized affidavit, a copy of which was then sent to the Civil Government. Upon its approval, the provincial government would then submit the necessary documents to the Ministry of Public Works. The cooperative's administrators were required to publish the cooperative's bylaws and deed of incorporation in the Official State Bulletin, as well as in the corresponding provincial bulletin. Cooperatives with a variable number of investors and capital could «adopt the legal form which its members considered most convenient ${ }^{27}$. Some cooperatives apparently did not trust the guarantees of freedom of association, assembling and religion enshrined in the 1869 Constitution. Many cooperative bylaws published in the Official State

${ }^{23}$ The committee included Santiago Diego Madrazo, José Echegaray (president), Eduardo Chao and Manuel Pastor y Landera (secretary). Tomas María Mosquera Pastor y Landera was not an economist, though he had a close relationship with Laureano Figuerola and José Echegaray, having studied for some time at the Escuela de Ingenieros de Caminos in Madrid. Chao was named Minister of Public Works a few months later and signed off on the bill. During his tenure in the Ministry, Echegaray wrote the bases for the Commercial Code of 1869, while Figuerola was part of the Codification Commission from the start.

24 «consignarse en escritura pública en una de las formas que prescribe el Código de Comercio en su sección primera, título II del libro $2 »$.

25 «Las sociedades que legalmente no tengan el carácter mercantil, y las cooperativas en las que ni el capital ni el número de socios es determinado y constante, podrán adoptar la forma que los asociados crean conveniente establecer en la escritura fundacional».

26 This dual nature of the cooperative could also be observed in other countries. In France, Article 1832 of the Civil Code established that all not-for-profit associations, including cooperatives, were not covered under the business code. German law, on the other hand, treats cooperatives as businesses for most purposes under the business law, even though cooperatives themselves are not part of that code. This principle extends to other entities; the GmbH, for example, is treated as a business even when it is explicitly a not-for-profit entity.

27 «adoptar la forma legal que sus miembros consideren más conveniente». 
Bulletin contain articles stating that they were in no way associations created for the debate and discussion of politics or religion. This claim was made in order to prevent any opposition from civil authorities ${ }^{28}$.

\section{COOPERATIVES IN THE COMMERCIAL CODE OF 1885 AND ITS PRECEDENTS}

The first steps toward the commercial code of 1885 were reflected in the principles published in 1869 by Echegaray, the then Minister of Public Works $^{29}$. This document stressed the need for radical reforms to the existing legislation on two issues: "associations and bankruptcy, both of which at this time are incomplete». Associations, particularly cooperatives, received special focus during these early stages. For Echegaray, the cooperative was defined by two characteristics: mutual insurance and the sharing of dividends as a compensation for labor. He argued that cooperatives did not fall under the commercial code since neither their objectives nor their labor compensation was economic in nature. Mutual insurance societies were excluded from the code for the same reason. One would have expected the Sixth Commission on the commercial code to have thoroughly revised laws on business entities according to the guidelines set by Echegaray ${ }^{30}$. However, the committee's minutes show that the revisions were not as extensive as the decree had announced. Debates regarding the legal form of business enterprise were brief and reflected consensus. In the final draft of the new Commercial Code, the number of business forms was expanded beyond the original three included in 1829. The new Code did not explicitly include cooperatives. However, Article 142 allowed firms to adopt any form necessary to achieve their ends, so long as their agreements did not contradict

28 The 1869 Spanish law echoes the 1867 French law on variable capital companies. Cooperatives were thus a means of introducing into the Spanish milieu something close to a limited-liability jointstock company with a charter flexible enough to allow the number and identity of investors to fluctuate freely. Though French cooperatives were not explicitly mentioned within the text of this Spanish law, they could in fact be incorporated as joint-stock companies, a business entity free from the limitations of general partnerships and the intricacies of public limited companies. Capital, unless company bylaws specified otherwise, was to be divided into registered shares (Art. 49), and the number of investors could fluctuate without requiring the dissolution of the company. Full incorporation was formalized once 10 per cent of the capital stock was paid in (Art. 50). In addition, the company had legal personality and the legal capacity to take administrative action and appear before the law (Art. 52). In contrast, the Spanish law of 1869, instead of allowing its incorporation as a jointstock company, explicitly recognized the cooperative as a separate legal entity.

29 «Decreto disolviendo la comisión encargada de revisar el Código de Comercio y la ley de Enjuiciamiento mercantil, y mandando nombrar otra que proceda a la redacción de un proyecto de Código y de Enjuiciamiento mercantil»(La Gaceta, n. 26, 24.09.1869).

30 Presided over by Gómez de la Serna; with Francisco Camps as secretary; and Figuerola, Cirilo Álvarez, Díaz Pérez, Luis María Pastor, Alonso Martínez and Joaquín Sanromá as members of the committee. Francisco de Paula Canalejas, Colmeiro and González Marrón would join later (Official State Bulletin, n. 151, 31.05. 1881). 
other law. The code was also open to the possibility of other entities ${ }^{31}$. The Commercial Code only covered those cooperatives that were engaged in acts of commerce «unrelated to mutual insurance or those engaged in one-time, specific commercial undertakings...» (Art. 143) ${ }^{32}$. This echoed the precepts of 1869 , according to which cooperatives possessing mercantile characteristics were to become business entities endowed with legal personality ${ }^{33}$. This draft did not specify the modus operandi of commercial cooperatives, the type of transactions they were allowed to carry, or their internal operations. Its wording would be later incorporated into the 1882 draft code and would make its way in the final draft of the Commercial Code enacted in 1885. Compared to the specific and elaborate treatment of cooperatives in other European countries, the Spanish approach was, as we shall see, imprecise.

\subsection{Cooperatives in the Mediterranean Region under Other Commercial Codes of the 1880s}

Spain's neighbors Italy and Portugal also revised their commercial legislation in the 1880s. Italy and Portugal paid special attention to the clear definition of commercial cooperatives and to the similarities between their operation and that of corporations. Italy enacted a new commercial code in 1883, 2 years prior to Spain. This code contained a detailed description of cooperatives as legal entities. Eight of the code's articles were devoted to defining the operations, rights of members and the legal framework put in place to foster the development of cooperatives ${ }^{34}$. Cooperatives were only covered under the commercial code if they were commercial in nature (Art. 219), in which case incorporation followed the guidelines set for public limited companies (Art. 221) ${ }^{35}$. There are two important features in this

31 «Art. 142. Por la índole de sus operaciones, podrán ser las compañías mercantiles: sociedades de crédito; bancos de emisión y descuento; compañías de crédito territorial; compañías de minas; bancos agrícolas; concesionarias de ferro-carril y obras públicas; de almacenes generales de depósitos; y de otras especies, siempre que sus pactos sean lícitos y su fin la industria o el comercio».

32 «Art. 143. Las compañías mutuas de socorros contra incendios de combinaciones tontineras sobre la vida para auxilios a la vejez y de cualquiera otra clase y las cooperativas de producción de crédito o de consumo, sólo se considerarán mercantiles y quedarán sujetas a las disposiciones de este Código, cuando se dedicaren a actos de comercio extraños a la mutualidad o se convirtieren en sociedades a prima fija».

33 This last point, concerning legal personality, would not be cleared with the enactment of the 1889 Civil Code. The code established that all professional partnerships (sociedades civiles or «civil enterprises») could adopt any of the business entities detailed in the Commercial Code, thus obtaining the legal personality to do business and obtain credit.

34 Articles 221-228: Sezione VII, Disposicioni riguardante le societá cooperativa. Book I. Title IX, Codice di Comercio Italiano (1883).

35 Article 76 established that for a cooperative to be considered commercial, it had to have as a purpose one or more acts of commerce. This indicates a French legal influence, contrary to what would have been expected, considering that Luzzatti, one of the salient figures of the first cooperative movement, had been inspired by Schulze-Delitsch. 
characterization: first, a cooperative was considered commercial if it sought profit, which coincided with the Roman-French conception of a business enterprise, rather than with the Germanic model, in which classification depended on legal form rather than aim; second, a cooperative was formally defined as a special type of corporation, offering limited liability to its members, something again in line with the influence of French commercial law.

Portugal also wrote cooperatives into its Commercial Code of $1888^{36}$. The Portuguese code defined cooperative societies on the basis of their variable capital stock and potentially unlimited number of investors (Art. 207). Cooperatives had to assume one of the following business forms: an ordinary partnership, limited partnership or public limited companies (Art. 105). In some respects, they were bound by the same regulations as public limited companies (Art. 209). Cooperatives could opt for either limited or unlimited liability (Art. 207 , item 3), and they were exempt from stamp duties and enterprise taxes ${ }^{37}$.

The lack of similarly detailed cooperative legislation in Spain apparently did not lead to any complaints. This is surprising; legal discussions in Spain display a keen understanding of contemporary developments in France, Italy and Portugal. This is perhaps because a new law on associations, which was to include general provisions on the cooperative, was already in the works.

\subsection{Cooperative Law in the United States}

Cooperatives have never played a large role in the U.S. economy, but their legal history in that country illustrates some of the issues at stake in the Spanish case. Most of the U.S. States had general incorporation since the 1840s, and corporations were especially numerous. The ease of incorporation in the U.S. meant that many fairly modest enterprises had the corporate form, and Americans were more accustomed to this form of organization than would be the case elsewhere. Thus, there should be no surprise that many cooperatives in the U.S. first organized as corporations, under the same statutes as would apply to business firms. Unfortunately for the cooperatives, however, most U.S. states in the late $19^{\text {th }}$ century had fairly rigid rules governing voting in corporations, the distribution of profits and other matters.

These rules might have made sense as measures intended to protect shareholders in a business firm, but they made adherence to Rochdale-like principles impossible, and created awkward issues even when not doing so. For example, many states insisted that voting rules within a corporation follow one-share, one-vote rules, which make the democratic structure of a cooperative incompatible with acquiring greater capital by having some

36 Title II, Chapter V, disposicoes especiais as sociedades cooperativas, Portuguese Commercial Code.

37 This treatment of liability is similar to the relevant provisions of the German cooperative law of 1889 . 
members buy more than one share. Similarly, some states required that dividend distributions be strictly proportional to investment. Cooperatives, on the other hand, often distribute profits following a formula that gives members an incentive to do business with the entity, which in the U.S. case would be forbidden. Finally, some corporation statutes required a minimum capitalized in excess of what cooperatives wanted or could raise. Thus, apparently, many cooperative institutions in the U.S. were at first unincorporated, that is, without any legal status at all.

Eventually, most U.S. states enacted specific legislation specifically tailored to cooperatives. The first, Michigan (1865), treats the cooperative as a sort of corporation with special rules. The next, Massachussetts (1866), defined the institution more broadly and clearly owes its inspiration to the English Friendly Societies' Acts. These and later measures made it possible for cooperatives to acquire legal status without submitting to the rigid corporate law of the time. These measures did not solve all the cooperatives' legal problems, however, as some common features of cooperative practice (such as «maintenance agreements» which required a farmer to sell out his output to his cooperative, or pay a fine to the cooperative) contravened the common law or the emerging anti-trust law ${ }^{38}$.

\section{THE SPANISH LAW ON ASSOCIATIONS OF 1887: COOPERATIVES AS PARTNERSHIPS}

The civil liberties proclaimed by the Revolution of 1868 and ratified in the Constitution of 1869 had not been fully secured. The Constitution of 1874, which marked the beginning of the Bourbon Restoration, sought to once again protect freedom of association for commercial aims: "Every citizen of Spain has the right $[\ldots]$ to assemble for the purpose of their livelihood» $\left(\right.$ Art. 13) ${ }^{39}$. It also specified that the essential freedoms of the press, association and assembly would be governed by a special law (Art. 14). The first legislative proposal, the «Bill on Workers' Associations», was presented to the Senate in December 1876 but failed to pass. That same year, the International Workers' Association was outlawed, the first step in a wave of repression against all worker-related associations. Beginning in 1881, the government's stance toward organized labor became more tempered and conciliatory; a new law was proposed on the issue of freedom of association, and though the bill never reached the floor, it did lay the basis for the new law that was eventually passed ${ }^{40}$.

\footnotetext{
38 Nourse (1927) discusses the law generally. Woeste (1998, especially Ch. 3) discusses the emergence of state cooperative statutes.

39 «Todo ciudadano español tiene el derecho [...] de reunión para los fines de la vida» (Art. 13)

40 For a more detailed review on labor legislation during this period, please refer to Alarcón Caracuel (1975) and Olías de Lima Gete (1977).
} 
Between 1881 and 1887, and in parallel with the association movement, the ideological movement known as Neo-gremialismo began to make headway $^{41}$. This movement sought to restore old craft-union structures in order to bring workers and employers back together under one association by adapting these institutions to a modern liberal context. A bill on these «new» organizations was presented before Congress in 1882 — Bill Setting the Terms for the Formation of Unions (May 28, 1882)». One of its clauses states that other associations, such as cooperatives, could be legally created within a union (term 3) (Alarcón Caracuel 1975, pp. 259-260). This development suggests that cooperatives had lost their alleged revolutionary character, and instead were now an instrument for society's most conservative elements. After several drafts, the general law on associations was passed in 1887 and remained in force until 1964. This law dealt primarily with administrative procedures, unifying the existing protocols governing the most recent forms of popular associations. Rising government interest in these entities led the Ministry of Public Works to create a registry of all Spanish associations by conducting a special survey (1897). The results revealed the existence of over 3000 associations, of which 80 , or fewer than 3 per cent of the total, were cooperatives $^{42}$.

The law established the cooperative as a form of sociedad civil (a «civil enterprise» or professional partnership), regardless of whether its purpose was "production, credit, or consumption» (Art. 1), as well as outlining the legal requirements for its incorporation. The law of 1887 was straightforward when compared to the law on joint-stock companies and credit institutions of 1869. It did not require the publication of bylaws in the Official State Bulletin, and observance of the publicity principle simply entailed informing the civil government and the appropriate legal authorities. The 1887 law was silent on the cooperative's internal structure: there were no guidelines on management structure, and nor were there formal rules for dealing with third parties, as in the case of credit operations (Ponsa Gil 1924, p. 84). This last point changed with the enactment of the 1889 Civil Code, which awarded legal personality to all associations.

\section{THE LAW ON AGRARIAN SYNDICATES (1906) AND THE LAW ON COOPERATIVES (1931)}

The arrival of the $20^{\text {th }}$ century brought with it a new awareness of the cooperative movement, which slowly continued to spread across Spain.

41 For more on the neo-gremilismo movement, see: Pérez Pujol (1872), Marlaud (1975), Capitán Díaz (2000).

42 "A summary of the societies of every kind existing in Spain as of January 1, 1887, with a description of their purposes according to the official data made available by the General Directorate». Quoted in Castillo (1994, pp. 403-404). 
The Law on Agrarian Syndicates of 1906 (and companion regulations of 1908) created a legal framework that proved beneficial for agricultural cooperatives and created a new legal form under which they could thrive: the agrarian syndicate ${ }^{43}$. In Article 1, Section 8, the law stated that those rural "cooperative institutions» involved in agricultural activities which adopted the agrarian syndicate as their legal form would be entitled to a variety of tax benefits, as well as legal personality as defined in Article 38 of the 1889 Civil Code. Both in essence and form, this law was inspired by French legislation. While France's trade union law of 1884 did not specifically authorize the creation of cooperatives, its wording was ambiguous enough to suggest that all entities «promoting common interests» could be set up as unions, an ambiguity that cooperatives used to their advantage. This legal device is identical to that embedded in the 1884 French law, and appears to reflect French influence.

This new law established in Spain a process of approval and legalization much simpler than the one under the law on associations of 1887. The law also defined the (essential) rights of members and a body of regulations. The success of this law resided in the assortment of tax exemptions (stamp duties, property taxes, etc.) and customs benefits offered by its regulations (Salinas Ramos 1976a, 1976b; Senent 2006). It was a law conducive to the development of agricultural cooperatives, particularly those dedicated to credit, and more specifically to what came to be known as Cajas Rurales, rural savings and loans associations based on the Raiffeisen model ${ }^{44}$. This, however, only helped bring confusion over what was meant by the term cooperative by introducing the new term "agrarian syndicate» as a category under which cooperatives could be included.

A positive externality of the new law was the proliferation of nonagricultural cooperatives, which were still subject to the 1887 law on associations. From the beginning of the $20^{\text {th }}$ century, there had been a continuous effort within the Associations Section of the Social Reforms Commission to compile basic statistics on cooperatives, which, though scarce, suggested the importance of consumer cooperatives. During the 1910s, the Associations Section put together several reports that imply considerable interest in the subject. The view that a specific law on cooperatives was needed would gain influence in the years to follow. In 1927 published what was this period's most full-fledged draft of law on the issue. Much of the law on cooperatives of 1931 derived its content from this preliminary document. The period between the drafting of the bill and the enactment of the final law was so protracted that several countries in Latin America passed their own laws

43 «Regarding new law on agrarian syndicates: Ley considerando sindicatos agricolas ... » (1906); Reglamento provisional para la aplicación de la ley sobre sindicatos agrícolas ... (1907); Reglamento para la ejecución de la ley de 28 de enero de 1906 ... (1908).

44 For more on the spread of Raiffeisen cooperatives in Spain, see Martínez Soto (2003). 
based on the Spanish bill, even before the legislation actually existed in Spain (Reventos Carner 1960).

One of the 1931 law's main objectives was delimiting the kinds of organizations that could register as cooperatives. The law and its corresponding regulations made explicit that only associations organized under this law could use the designation "cooperative» (Art. 6); all others would be fined (Regulations, Art. 27). Spain's first general law on cooperatives traced its roots back to the Rochdale Principles, advocating an open-door policy and democratic vote, as well as the creation of a reserve fund and a compulsory social fund ${ }^{45}$. For the first time, a cooperative was explicitly defined by law:

«Art. 1. A Cooperative Society shall be understood as an Association of natural or legal persons, which in its organization and operation abides by the terms of the present Decree and does not seek profit, with the object of satisfying a common need for the social and economic betterment of all its members through joint action in a collective endeavor ${ }^{46}$.

The law also required that cooperatives adhere to a number of basic rules. As a general rule, control was to be democratic, following the principle of "one man, one vote». Cooperative management had to be in the members' hands; management by external parties was expressly forbidden. Cooperatives were to have a board of directors, as well as an assembly or general meeting of members in charge of management. Cooperatives with 100 members or more were required to appoint an auditing committee ${ }^{47}$.

Any surplus was to be divided among the members in proportion to their input into the cooperative's activities. Article 13 established that 10 per cent of a cooperative's annual returns were to be set aside as part of a reserve fund, until the point where the amount in this fund was equal to the total capital stock. There were also special requirements on the destination of funds for community projects (Art. 27 and Art. 44). Shares were only transferable between cooperative members. The law also envisaged the creation of unions and federations of cooperatives, as well as their economic integration (Art. 37). The degree of liability to third parties was either limited, unlimited or subject to assessment. Incorporation of cooperatives did

\footnotetext{
${ }^{45}$ The social fund consists of earnings set aside to contribute to a local public good such as a school.

46 «Art. 1. Se entenderá por Sociedad Cooperativa la Asociación de personas naturales o jurídicas que, sujetándose en su organización y en su funcionamiento a las prescripciones del presente Decreto y tendiendo a eliminar el lucro, tenga por objeto satisfacer alguna necesidad común procurando el mejoramiento social y económico de los asociados mediante la acción conjunta de éstos en una obra colectiva».

47 Woeste (1998, p. 20) discusses the Rochdale principles. Montolio Hernández (2006) argues that this executive structure clearly differs from the German dual model.
} 
not require a notarized public deed. The only essential requisite was registration before the Ministry of Labor, which was formalized once the cooperative's bylaws and regulations received ministerial approval. While registration was free of charge (Art. 7), cooperatives were not exempt from bookkeeping (Art. 38), and were bound by law to submit records and proceedings, balance sheets and statements of profits and losses, as well as informing of any changes in their administrative bodies and facilitating inspection and auditing (Art. 39).

With the onset of civil war, this law had little impact on the cooperative movement. The Franco regime enacted its own legislation in 1942.

\section{HOW MANY COOPERATIVES?}

Confusion over the early law on cooperatives has led much of the Spanish historiography to ignore the existence of cooperatives in the $19^{\text {th }}$ century. In this section, we document the number and type of such cooperatives, at least approximately. There are two obstacles to this goal. One is the need to assemble the information from a variety of dispersed sources. The other is that, as seen above, the law was not entirely clear on what qualified as a cooperative. We have no reason to doubt that, outside of agriculture, early Spanish cooperatives constituted a tiny fraction of the economy (Garrido 2007; Martínez Soto 2003). We focus on the evidence available for the period prior to 1931, when the law clarified the status of cooperatives and also began to collect regular statistics on them.

The first references to cooperatives dated back to the 1850s. All were apparently producer cooperatives such as «The proletariat of Valencia» (1856) or «The Producers Association Buñol» (1857), also in Valencia. Information on this budding cooperative movement comes in newspapers such as «The Worker» (El Obrero) or «Association» (La Asociacion) — both Catalan. Numerous articles in these publications discussed cooperatives. This apparently enthusiastic support for cooperatives cooled when the first labor organizations decided that cooperatives did not have significant revolutionary potential ${ }^{48}$.

The indirect evidence on cooperatives may not reflect agreement on what was understood to be a cooperative. To err on the side of caution, we adopt a conservative criterion: the government definition. That is, what we take as a cooperative includes all entities that the government allowed to register as such. The cooperative appears for the first time in a legal text on the «Law for free creation of joint-stock and credit companies» (Ley de libertad de creación de sociedades por acciones y de crédito). The law stipulates that cooperatives

48 One of the key issues for the Catalan Workers' Congress held in 1865 was the possible role of cooperatives in the workers' struggle. The First Spanish Workers Congress (June 19, 1870) discussed the issue extensively and concluded that cooperatives were not useful for the workers' movement (Reventos Carner 1960, pp. 92-94). 
adhere to publicity requirements similar to those for a corporation. Once the authorities approved a cooperative's statutes, they would be advertised in the Madrid Gazette. Garrido (1879) reports that 600 such cooperatives were founded between 1868 and 1874. Our examination of the Gazette yields a much lower estimate, not quite $20 .{ }^{49}$ The names of some of these entities leave no doubt as to their form and purpose. We find, for example, «The workers co-operative society for the Chocolate Factory D. Matías López (Cádiz)» and the "Great Thought society for rewarding virtue and labor» (Sociedad cooperativa de socorros y premios a la virtud y el trabajo El Gran pensamiento; Madrid).

The first official figures on cooperatives appear in the statistics of associations preserved in the Historical Archive in Madrid. From this "Summary of companies of every kind existing in Spain on January 1, 1887», which also includes the firm's purpose and legal form, we count a total of 39 cooperatives. The regions with the highest number of cooperatives are Madrid (9), Valencia (7), Murcia (7), Oviedo (5) and Catalonia (4). The 1887 tabulation does not include a single cooperative in the province of Barcelona, which seems suspicious. Two cooperatives in Tarragona consisted of «cooperative sailors" and may indicate that some older guilds adopted the new legal form. Most of Valencia's cooperatives were for consumption and production. Some were apparently intended for the employees of specific enterprises; one was run by the Ateneo Commercial and Savings Bank, and another by the pawnshop. Middle-class cooperatives were especially numerous in Madrid, where cooperatives included organizations for teachers, for private-school teachers and for employees of the Stock Exchange, among others. Murcia, for its part, had two medical and pharmacy cooperatives. This cooperative type never did well, facing stiff opposition from pharmacist organizations. With two exceptions, all cooperatives had been approved by the Civil Governor, reinforcing our view that these statistics reflect the official definition of cooperatives.

In 1895, the economist J. Díaz de Rábago compiled the first systematic cooperative statistics by asking all provincial governments for copies of their enterprise registers (Díaz de Rábago 1895, pp. 276-333). He concluded that in that year, Spain had 138 cooperatives distributed across consumption (87),

49 Specifically: Cooperativa de consumo de la Asociación de Amigos del País Aragonesa (Zaragoza); Cooperativa de Consumo de Valencia; Sociedad cooperativa de la Calle Jesús y María (Madrid); Sociedad cooperativa de Córdoba; Sociedad cooperativa de agricultores de Córdoba, Sociedad cooperativa para el fomento de las Artes (Sevilla); La Igualdad - Sociedad Cooperativa de Artesanos (Málaga); La Unión (Valencia); Sociedad cooperativa agrícola Trebujena (Trebujena-Cádiz); Sociedad cooperativa de Alimentación y ornato de Badajoz; Sociedad cooperativa y Agrícola de Trebujena Numero 1 (Trebujena-Cádiz); Cooperativa de Braceros (Albacete); Cooperativa Gaditana de Fabricación de Gas, SA (Cádiz); Sociedad cooperativa creada por D. Camilo Botella (Madrid); Sociedad cooperativa de obreros de Alicante; Cooperativa de empleados municipales (Murcia); Sociedad cooperativa para los obreros de la fábrica de Chocolate de D. Matías López (Cádiz); Sociedad cooperativa de socorros y premios a la virtud y el trabajo El Gran pensamiento (Madrid). 
production (39) and credit (12). His estimates imply a considerable increase over the 1887 figures. Especially striking in his estimate is the region of Valencia with 65 cooperatives. For this region, Díaz de Rábago relied on a study by Pérez Pujol (1872), and we suspect that the Valencia figure reflects some double-counting. Following Valencia in this tabulation was Catalonia with 19 cooperatives, Andalusia with 18 and Madrid with 12. The apparent rise of Andalusia contrasts with the apparent loss of registered cooperatives in the north of Spain, but this change may again reflect errors in the source. For example, we know that the Workers Cooperative Society in Barakaldo (1884), Consumer Cooperative Sestao (1887) and the Workers' Cooperative Union of Araya (Hermua 1887) were all operating in the Basque country, yet they do not appear to be in Díaz de Rábago's count (Rousell and Albóniga 1994).

New interest in cooperatives in the $20^{\text {th }}$ century led to more systematic data collection. There are two especially useful tabulations, one for 1915 and another for 1931. The statistics for 1915 were developed by the third section of the Institute of Social reforms are contained in the «Preview of the census of associations» undertaken in 1915. This source lists only the number of cooperatives by province. We have aggregated up to the regional level to maintain consistency across sources. We also refined the data, as some cooperatives were registered under slightly different rubrics. Data for 1932 reflect the legal definition of a cooperative in 1931, when Spanish law first clearly defined the concept.

The patterns evident in the $19^{\text {th }}$-century estimates are also clear in Table 1. Most cooperatives are in Spain's eastern regions, and consumer cooperatives dominate. Catalonia comes first, with 304 cooperatives, of which five-sixths are consumer cooperatives. ${ }^{50}$ In both Valencia and Andalucía, the most common cooperative type was also the consumer cooperative.

Table 2 summarizes the 1931 data on cooperatives. The cooperative taxonomy given in the 1931 law contains 25 categories, plus two catch-all groups for those «mixed and indeterminate» cooperatives and those not classified. In that year, we find a total of 592 cooperatives, of which 42 per cent are consumer cooperatives. Agricultural cooperatives had grown to nearly one-fifth of all institutions, and the growing demand for decent housing is reflected in the 17 per cent of cooperatives that were for housing. The remaining 25 categories accounted for only 22 per cent of the total. In comparison with the 1915 statistics, it appears that the cooperatives for production and credit had lost ground. But this difference may reflect the many agricultural cooperatives that had not appeared as such in the

50 For Catalonia, we have an additional source that indicates a possible problem with the 1915 tabulation. The Social Yearbook published by the Social Museum (Museo Social) for 1914-1915 indicates that only 193 registered cooperatives in Catalonia were actually operating. We lack a parallel source for the other regions, but it is possible that a similar discrepancy existed elsewhere. 
TABLE 1

COOPERATIVES BY PROVINCE AND TYPE, 1915

\begin{tabular}{|c|c|c|c|c|c|c|c|}
\hline Province & $\begin{array}{l}\text { Production } \\
\text { cooperative }\end{array}$ & $\begin{array}{c}\text { Credit } \\
\text { cooperative }\end{array}$ & $\begin{array}{c}\text { Consumer } \\
\text { cooperative }\end{array}$ & $\begin{array}{c}\text { Housing /construction } \\
\text { cooperatives }\end{array}$ & $\begin{array}{c}\text { Medical } \\
\text { cooperatives }\end{array}$ & $\begin{array}{l}\text { Other } \\
\text { types }\end{array}$ & $\begin{array}{c}\text { Total } \\
\text { cooperatives }\end{array}$ \\
\hline Andalucia & 5 & 13 & 99 & 24 & 3 & 34 & 178 \\
\hline Aragon & 0 & 11 & 23 & 2 & 0 & 12 & 48 \\
\hline Baleares & 0 & 1 & 15 & 2 & 1 & 6 & 25 \\
\hline C.Leon & 0 & 5 & 52 & 3 & 0 & 5 & 65 \\
\hline C.Mancha & 0 & 7 & 32 & 2 & 0 & 1 & 42 \\
\hline Canarias & 1 & 0 & 0 & 1 & 0 & 2 & 4 \\
\hline Cataluña & 5 & 10 & 252 & 4 & 1 & 32 & 304 \\
\hline Extremadura & 1 & 4 & 11 & 0 & 0 & 21 & 37 \\
\hline Galicia & 0 & 3 & 11 & 0 & 0 & 0 & 14 \\
\hline logroño & 0 & 0 & 2 & 0 & 0 & 1 & 3 \\
\hline Madrid & 1 & 7 & 5 & 1 & 1 & 2 & 17 \\
\hline Murcia & 0 & 2 & 30 & 0 & 0 & 5 & 37 \\
\hline Navarra & 0 & 0 & 4 & 0 & 3 & 1 & 8 \\
\hline Oviedo & 0 & 0 & 30 & 0 & 0 & 0 & 30 \\
\hline Paisvasco & 2 & 15 & 38 & 1 & 4 & 4 & 64 \\
\hline Santander & 0 & 0 & 13 & 0 & 1 & 3 & 17 \\
\hline Valencia & 2 & 33 & 95 & 7 & 0 & 32 & 169 \\
\hline Total & 17 & 111 & 712 & 47 & 14 & 161 & 1062 \\
\hline
\end{tabular}


TABLE 2

COOPERATIVES BY PROVINCE AND TYPE, 1931

\begin{tabular}{|l|c|c|c|c|c|}
\hline & Consumer & Housing & Agricultural & Other & Total \\
\hline Andalucia & 23 & 3 & 16 & 8 & 50 \\
\hline Aragon & 23 & 3 & 16 & 8 & 50 \\
\hline Baleares & 2 & 1 & 6 & 1 & 10 \\
\hline C.Leon & 19 & 6 & 5 & 5 & 35 \\
\hline C.Mancha & 10 & 1 & 8 & 8 & 27 \\
\hline C.Valencia & 19 & 24 & 34 & 22 & 99 \\
\hline Canarias & 1 & 1 & & 2 & 4 \\
\hline Catalonia & 56 & 4 & 11 & 46 & 117 \\
\hline Extremadura & 3 & 1 & 3 & 1 & 8 \\
\hline Galicia & 8 & 3 & 6 & 3 & 20 \\
\hline Logroño & 1 & & 1 & 1 & 3 \\
\hline Madrid & 13 & 6 & 3 & 15 & 37 \\
\hline Murcia & 4 & & 3 & 0 & 7 \\
\hline Navarra & 2 & & 1 & 1 & 4 \\
\hline Oviedo & 4 & 1 & 1 & 2 & 8 \\
\hline P.Vasco & 65 & 41 & 4 & 6 & 116 \\
\hline Santander & 7 & 2 & 3 & 102 & 438 \\
\hline Total & & & & 3 & \\
\hline
\end{tabular}

Source: Dirección General del Instituto Geográfico, Catastral y de Estadística (1932-1933).

classification of cooperatives under the Associations Act of 1887 (Ley de Asociaciones 1887 ${ }^{51}$.

In 1931, cooperatives were located mostly in Catalonia and the Basque Country. Catalonia continued its tradition of consumer cooperatives, but the region's economic development is reflected in new types of cooperatives suited to assisting members in their various businesses. The number of housing cooperatives is surprisingly low, given the industrial workforce in the area. But this fact may just reflect the difficulty of purchasing land in large cities like Barcelona. In the Basque country, over 90 per cent of cooperatives were for consumption, housing and agriculture. Housing cooperatives were by far the

51 See Plana i Gabarnet (1998), who relied on information reported in "El Cooperador» $(8,1914)$. On cooperative pharmacies, see Rivas Moreno. 
most numerous, reflecting efforts to provide accommodation for a population swollen by migration. Valencia's 99 cooperatives include a marked presence of agricultural cooperatives. Housing cooperatives were also important, nearly one-quarter of the total (almost 25 per cent of the total).

The advent of civil war rendered the 1931 Act moot for the cooperative movement. In 1942, after the civil war, the Franco dictatorship established a new legal regime for cooperatives. The statistical information on cooperatives available to us for 1931 and before is enough to suggest an important historical puzzle: long before the historical literature thinks Spain had cooperative law, it had cooperatives.

\section{CONCLUSIONS}

This discussion of the legislative framework for Spanish cooperatives highlights three important points for these institutions in Spain and elsewhere. First, in Spain as in some other European countries, the development of cooperative law was closely tied to the development of company law. Cooperatives and business firms have important differences, but at some level the issues that need to be confronted in shaping one apply with equal force to the other. In the Spanish case, we see specifically that allowing cooperatives to form was equivalent to tolerating general incorporation for a specific kind of enterprise. The Spanish case also illustrates the more general issue of the connection between enterprise law and the freedom of association. One reason cooperatives wanted a legal framework was to allow their members to work together without police surveillance.

Second, the Spanish case illustrates the precarious position of cooperatives between company law and civil law, and between a privileged entity and a tolerated one. The 1869 law never defined what a cooperative meant, and allowed cooperatives to organize as any of the then-extant legal forms. The draft Commercial Code published in 1869 (and enacted in 1885) indicates a clear intention to treat cooperatives as a type of corporation. But Spanish commercial law was built on the notion of profit, and eventually this definition made it awkward to treat the cooperative like other commercial entities. Thus, while France and other countries treated cooperatives as a species of business enterprise, Spain did not. The Spanish Law on Associations (1887) stripped cooperatives of the economic benefits gained with the law of 1869 .

Our final contribution is a corrective to the literature that dates the beginnings of Spanish cooperatives to the Agricultural Trade Act of 1906. This Act and the 1931 Cooperatives Act both proved very beneficial to the development of Spanish cooperation. However, we were able to document that cooperatives did organize under the earlier legislation discussed above. These early cooperatives are themselves worthy of fresh research on the role they played and how they operated. 
We stress the close ties between commercial law and the law governing cooperatives. The point would seem unremarkable to any $19^{\text {th }}$-century observer with experience of the two types of enterprise. Yet subsequent research has often focused on left-wing cooperatives and stressed the ideological reasons for cooperative movements. To contemporaries, some were doubtless tied to one or another social or ideological movement, but most were simply a way for individuals to combine to attain some concrete, shared goal. As such, they were very much like a partnership, a corporation or another business enterprise. We do not dishonor cooperatives by appreciating their roots in commercial organizations and commercial law.

\section{BIBLIOGRAPHY}

Alarcón CARAcuel, M. R. (1975): El derecho de asociación obrera en España (1839-1900). Madrid: Ediciones de la Revista de Trabajo.

BERNAL LlORÉNS, M. (2004): «La regulación de las sociedades anónimas y la información contable publicada en la «Gaceta de Madrid» a mediados del siglo XIX». Revista española de financiación y contabilidad 120, pp. 65-94.

Bernal, A., and Parejo, A. (2001): La España Liberal (1868-1913). Economía. Madrid: Síntesis.

CAPitán Díaz, A. (2000): Educación en la España Contemporánea. Madrid: Dykinson.

CASTILLo, S. (1994): Solidaridad desde abajo: trabajadores y socorros mutuos en España contemporánea. Madrid: UGT-Centro de Estudios Históricos.

Codice di commercio del regno d'Italia con la correlazione de'suoi articoli tra loro e con quelli degli altri codici e delle leggi speciali: corredato della relazione Zanardelli, della legge transitoria commerciale, del regolamento 27 dicembre 1882, di una tavola di confronto degli articoli del ... .1883. Roma: Tip. elzeviriana nel Ministero delle finanze.

Código de comercio de 1885: comentado y concordado, con el anterior y los extranjeros, por la redacción de la Revista general de legislación y jurisprudencia (1885): Madrid: Revista General de Legislación y Jurisprudencia.

Código de Comercio, decretado, sancionado y promulgado en 30 de mayo de 1829: Decretado, sancionado y promulgado en 30 de mayo de 1829 (1829): Madrid: Oficina de D. L. Amaritx.

Código penal español decretado por las cortes en 8 de junio, sancionado por el rey y mandado promulgar en 9 de julio de 1822 (1822): Madrid: Imprenta Nacional.

Diario de las Cortes Constituyentes (1869a): Proyecto de ley declarando libre la creación de sociedades anónimas y de crédito-Sesión de 22 de Marzo. Madrid: Imprenta Nacional.

Diario de las CoRtes Constituyentes (1869b): La comisión de Bancos reproduce el dictamen que retiró en 31 de mayo. $n^{\circ} 112$, Sesión de 28 de junio de 1869. Madrid: Imprenta Nacional. 
Diario de las CoRTEs Constituyentes (1869c): Intervención sobre la cooperativa y su tipología (entre otros asuntos de Sr Moret, 24 de marzo de 1869). Madrid: Imprenta Nacional.

Diario de las CoRtes Constituyentes (1869d): Intervención de. Sr. Garrido, 19 de julio [sobre la proposición que tiene por objeto el que las cortes conozcan el estado civil y de instrucción de las clases trabajadoras]. Madrid: Imprenta Nacional.

Diario de las Cortes Constituyentes (1869e): Apéndice Cuarto al número de 137, 11 de octubre 1869: Ley aprobada y sancionada por las Cortes Constituyentes declarando libre la creación de Sociedades anónimas y de crédito. Madrid: Imprenta Nacional.

Diario de las Cortes Constituyentes (1869f): Apéndice al $n^{\circ}$ 78: Dictamen de la comisión sobre el proyecto de ley declarando libre la creación de sociedades anónimas y de crédito. Sesión de 20 de mayo de 1869. Madrid: Imprenta Nacional.

Diario de las Cortes Constituyentes (1869g): Apéndice $1^{\circ}$ al $n^{\circ} .33$ : proyecto de Ley, presentado por el Sr. Ministro de Fomento, declarando libre la creación de sociedades anónimas y de crédito. 22 de mayo de 1869. Madrid: Imprenta Nacional.

Dirección General de Agricultura (1934): Censo estadístico de sindicatos agrícolas. Madrid: Publicaciones de Economía Técnica Agrícola.

Dirección General del Instituto Geográfico, Catastral y de Estadística (19321933): Anuario Estadístico de España de 1931. Madrid: Dirección General Agricultura, http://www.ine.es/inebaseweb/treeNavigation.do?tn=150156

GaLASSI, F. L. (2001): «Measuring Social Capital: Culture as an Explanation of Italy's Economic Dualism». European Review of Economic History 5 (1), pp. 29-59.

GARRIDO, F. (1879): La cooperación: Estudio teórico y práctico sobre las sociedades cooperativas de consumo y producción en Inglaterra y otros países, y especialmente en Cataluña. Barcelona: Imprenta de Oliveros.

GARRIDO, S. (1996): Treballar en comú: el cooperativisme agrari a Espanya: 1900-1936. València: Edicions Alfons el Magnànim.

GarRIDO, S. (2007): «Why Did Most Cooperatives Fail? Spanish Agricultural Cooperation in the Early Twentieth Century». Rural History 18 (2), pp. 183-200.

Gascón y Miramón, A. (1927): Hacia una ley de cooperativas. Madrid: Servicio de Publicaciones Agrícolas.

Gómez de la Serna, P. (1878): «Introducción Histórica», in D. Pedro Gómez de la Serna, and D. José Reus y García (eds), Código de Comercio arreglado a la reforma decretado en 6 de diciembre de 1868, acordada y concordada (...). Madrid: Imprenta de la Revista de Legislación, pp. 21-49.

GuinnANE, T. (2001): «Cooperatives as Information Machines: German Rural Credit Cooperatives, 1883-1914». The Journal of Economic History 61 (02), pp. 366-389.

Guinnane, T.; Harris, R.; Lamoreaux, N., and Rosenthal, J.-L. (2007): «Putting the Corporation in Its Place». Enterprise and Society 8 (3), pp. 687-729. 
Guinnane, T (2010a): New Law for New Enterprises: The Development of Cooperatives Law in Germany, 1867-1914. Working Paper (Mimeo).

Guinnane, T (2010b): Using a New Legal Form: The GmbH from 1892 to World War I. Working Paper (Mimeo).

Guinnane, T., and Martínez-Rodriguez, S. (2010a): "¿Fue alguna vez la cooperativa una sociedad por acciones? Leyes de negocios y de cooperativas en España (1869-1931)». Madrid: Documentos de Trabajo de la Asociación de Historia Económica, DT-0908, http://www.aehe.net/publicaciones.html

Guinnane, T., and, Martínez-Rodriguez, S. (2010b): «Did the Cooperative Start Life as a Joint-stock Company? Business Law and Cooperatives in Spain, 1869-1931». Madrid: Documentos de Trabajo FUNCAS, 567, http:// www.funcas.ceca.es/Publicaciones/Documentos_Trabajo.asp

Henriksen, I. (1999): «Avoiding Lock-In: Cooperative Creameries in Denmark, 1882-1903». European Review of Economic History 3 (1), pp. 57-78.

Ingalls, R., and Herrick, M. T. (1914): Rural Credits: Land and Cooperative. London: D. Appleton and Company.

Instituto Reformas Sociales (1915): Avance al censo de asociaciones. Madrid: Imprenta de la. Sucesora de M. Minuesa.

Ley considerando Sindicatos Agrícolas, para los efectos de esta, las Asociaciones, Sociedades, Comunidades y Cámaras Agrícolas constituidas o que constituyen legalmente para alguno de los fines que se expresan (1906): Boletín del Instituto de Reformas Sociales, 20, pp. 613-616.

Ley de Asociaciones (1887): Gaceta de Madrid, 193 (12.07.1887), pp. 103-105. Marlaud, A. (1975): La Cuestión social. Madrid: Ediciones de la Revista de Trabajo.

Martínez Soto, A. P. (2003): «El cooperativismo de crédito en España, 18901934: modelos, sistemas de gestión y balance de actuación». Historia Agraria 30, pp. 119-150.

Matilla Quiza, M. J. (1996): «Debates parlamentarios y leyes sobre la asociación de capitales (1810-1874)». Revista de Estudios Políticos 93, pp. 379-399.

Montolio Hernández, J. M. (2006): «En el 75 aniversario de la Ley de Cooperativas de 1931». La sociedad cooperativa 24, pp. 19-21.

Nourse, E. G. (1927): The Legal Status of Agricultural Co-operation. New York: MacMillan.

Olías de Lima Gete, B. (1977): La libertad de asociación en España (1868-1974). Madrid: Instituto de Estudios Fiscales.

Pérez Pujol, E. (1872): La cuestión social en Valencia. Dictamen que a la sección de Ciencias Sociales de la Sociedad Económica presión la comisión designada y el cual hubo de retirar después. Redactado por D. Valencia: Imprenta de José Domenech.

Petit, C. (1980): Compañias mercantiles en Bilbao, 1737-1829. Sevilla: Publicaciones de la Universidad de Madrid.

Piqueras Arenas, J. A. (1992): La Revolución Democrática (1868-1874): cuestión social, colonialismo y grupos de presión. Madrid: Ministerio de Trabajo. 
Plana i Gabarnet, G. (1998): El cooperativisisme catala o l'economia de la fraternitat. Barcelona: Universidad de Barcelona.

Ponsa GiL, J. (1924): Sociedades Civiles, Mercantiles y cooperativas de seguros, vol. I-II. Barcelona: Librería Bosch.

Real Decreto por el que se aprueban las bases para el futuro código de comercio, Gaceta de Madrid, 267, (24.09.1869).

Reglamento para la ejecución de la ley de 28 de enero de 1906 sobre Sindicatos Agrícolas, Gaceta de Madrid, 17, (17.01.1908).

Reglamento provisional para la aplicación de ley sobre sindicatos agrícolas en cuanto a las exenciones de los impuestos de Timbre, Utilidades y Derechos Reales, Gaceta de Madrid, 282, (09.10.1907).

Reventos Carner, J. (1960): El movimiento cooperativo en España. Barcelona: Ariel.

Rivas Moreno, F.: Cooperativas Farmacéuticas. Barcelona: Imprenta cooperativa.

Rousell, C., and Albóniga, N. (1994): Historia de las cooperativas vascas, http://www.ekkf-fecoe.coop/files/publicaciones/historia_coop_consumo.pdf

Rubio, J. (1950): Sáinz de Andino y la codificación mercantil. Madrid: Consejo Superior de Investigaciones Científicas.

Salinas Ramos, F. (1976a): "El primer marco jurídico del cooperativismo agrario (Ley de Sindicatos Agrícolas de 1906)». Estudios Cooperativos 39, pp. 41-74.

Salinas Ramos, F. (1976b): «El primer marco jurídico del cooperativismo agrario (Ley de Sindicatos Agrícolas de 1906) (continuación)». Estudios Cooperativos 40, pp. 49-76.

SARrión Gualda, J., and Espuny Tomás, M. J. (1989): Las Ordenanzas de 1766 del Consulado de Comercio de Cataluña y el llamado Proyecto de Código de Comercio de 1814 de la Diputación Provincial de Cataluña. Madrid: Ministerio de Justicia, Secretaría General.

Senent, M. J. (2006): "La llei de Sindicats Agricoles i la posterior evolució de la legislació cooperativa agraria», in M. J. Senent Vidal, S. Garrido, and P. V. Romero (eds), El Cooperativisme fins avui : llei de sindicats agrícoles (1906). Castelló de la Plana: Universitat Jaume I, Servei de Comunicació i Publicacions, pp. 11-38.

TAPIA, E. (1839): Elementos de Jurisprudencia Mercantil. Valencia: Librería de D. Ildefonso Monpié de Montagudo.

Tortella, G. (1968): «El principio de responsabilidad limitada y el desarrollo industrial de España: 1829-1869». Moneda y Crédito 104, pp. 69-84.

Tortella, G., and Schwartz, P. (1970): Ensayos de la economía española a mediados del siglo XIX. Madrid: Banco de España.

Woeste, V. S. (1998): The Farmer's Benevolent Trust: Law and Agricultural Cooperation in Industrial America, 1865-1945. Chapel Hill: The University of North Carolina Press. 